\title{
Conclusion
}

\section{A Catholic Women's Liberal Arts College}

The emphasis here has always been on women ... women's issues, women as an entity in life, women as being equal with men. ... Every opportunity was given women to develop equally as men developed.... This has been the saving grace.

—Mildred B. Otenasek '36

The blueprint for the building of the College of Notre Dame detailed with principles of truth, spirit, and love, was never rolled up gently and placed in a drawer.... The plan was lived by all who once were here, by us who are here now; and it will be carried on by those who are yet to come.... The general design is complete.

—Damozel, 1949

As this book has argued, Catholic higher education for women emerged and took shape under a variety of cross-pressures. Catholic sisters followed Protestant and secular trends in creating colleges to form young women to succeed intellectually and spiritually, whether in marriage and motherhood, in a profession, or as a member of a religious order. Small female colleges proliferated in part because multiple orders established colleges to educate their own parochial schoolteachers and graduates. The Baltimore experience, with minor variations, was typical. The School Sisters of Notre Dame established the Institute of Notre Dame in 1863 and obtained a state charter the following year. Within four years, the Sisters of Mercy opened a second girls' school in the Mount Washington section of the city, Mount Saint Agnes Academy. ${ }^{1}$ In 1890 they obtained a state charter for Mount Saint Agnes Collegiate Institute, with a clause giving it power to confer bachelor's degrees; it now competed for students with the Institute of Notre Dame and the Notre Dame Collegiate Institute. In 1896, as the College of Notre Dame completed its inaugural academic year, the Sisters of Mercy renamed their school Mount Saint Agnes College. Although small in size, Mount Saint Agnes College adversely affected the College of Notre 
Dame by competing with it for students and philanthropic funds within the local Catholic community. ${ }^{2}$ This soon became a common development pattern in dioceses nationally.

Bishops, for their part, believed that if higher education for women had to exist at all, nuns were obligated to provide it, both to keep young Catholic women out of secular institutions and increasingly to provide a legally qualified workforce of nuns for the church's parochial schools and hospitals. Since these institutions were essentially cost free to the episcopacy, and since they provided major benefits to local dioceses, bishops got over their initial reservations about women's higher education and encouraged their rapid expansion. As chapter 1 recounted, Cardinal Gibbons was vigorously promoting plans for Trinity College even before the College of Notre Dame had graduated its pioneer class in 1899. Catholic women's colleges multiplied as Gibbons's fellow bishops followed his example nationally. Although mainstream women's colleges were concentrated in the East, their Catholic counterparts spread to all parts of the country in order to accommodate the growing Catholic population. Since most of these families could not afford to send their daughters to established residential colleges like the College of Notre Dame, the College of New Rochelle, and Trinity College, local bishops encouraged, and occasionally ordered, sisterhoods to open colleges to accommodate day students.

Church-related men's colleges were fewer in number and had larger enrollments than women's colleges. By 1932-33, of eighty-nine regionally accredited Catholic colleges, thirty-nine men's institutions enrolled 55,587 students, an average of 1,425 students per school, whereas fifty women's colleges enrolled 10,450 students, an average of $209 .{ }^{3}$ Of the seventy-four Catholic women's colleges operating nationwide in 1930, 62 percent did not meet the requirements of regional accrediting agencies. ${ }^{4}$ Nevertheless, by the mid1960s, Catholic women's colleges had expanded still further. From the late nineteenth century through the 1940s, teaching sisterhoods had responded to state and church demands by opening normal schools in their motherhouses for their young members. When the Sister Formation Movement of the 1950s called for young sisters to hold college degrees before commencing their work as parochial school teachers, a number of these normal schools developed into four-year colleges that admitted laywomen.

Expansion of these institutions soon grew beyond what could realistically be supported. According to Rev. Edward V. Stanford, a consultant for the Association of American Colleges, by 1950 "Pennsylvania had 18 senior Catholic colleges, nine for women, six for men and three partly coeducational institutions." ${ }^{\circ 5}$ Between 1950 and 1964, five more women's colleges 
appeared, and plans for another male and two more female institutions were in the offing. Three of the new female colleges were in metropolitan Philadelphia, which according to a report in the New York Times "already had three Catholic colleges for women and three for men."' Typical of many of his peers, Archbishop John J. Krol was "unconvinced that nine colleges were too many."7 Catholic women's colleges were smaller, on average, than their secular counterparts. In eastern states in 1970, their full-time enrollments averaged 685, while enrollments in Seven Sister colleges ranged from 2,336 at Smith to 790 at Bryn Mawr. ${ }^{8}$

But in 1964, the year Archbishop Krol hoped for yet more colleges to open in Philadelphia, the postwar educational expansion was already reaching its outer limits. Only a few years later, long-simmering financial, enrollment, and staffing crises erupted into full view, threatening the viability of Catholic institutions ranging from larger men's institutions to tiny women's colleges. The crisis was particularly acute in the latter. With their enrollments dropping and financial problems rising, many closed their doors or merged with local formerly men's colleges. Others turned quickly to coeducation. The total number of US women's colleges declined by nearly 70 percent, from 233 to 74, between 1960 and 2000; many of these were Catholic. ${ }^{9}$ Only a small minority, among them the College of Notre Dame, were able to remain single-sex colleges. Meanwhile, in the 1960s and 1970s, the Horace Mann and Roemer cases had forced the College of Notre Dame to reexamine the links between its religious affiliation and its secular mission. As the presence of religious communities on campuses began to decline sharply in these decades, many colleges' long-held vision of their identity became a matter of campus-wide debates, and Notre Dame was no exception. How was it to honor Catholic values without being "sectarian"? Were its religious tradition and spirit affected by the struggle to qualify for government funding? What would be the consequences of the swift post-1970 transition from religious to lay leadership? The College of Notre Dame had to wrestle with its identity and viability as a Catholic women's college during the post-Vatican II decades as it faced external and internal challenges to both.

\section{Loyola College and the Threat to Single-Sex Education}

As earlier chapters have discussed, Catholic men's colleges, while they often allowed their faculty to lecture part time at nearby women's colleges, seldom saw those institutions as peers. In October 1899, a few months after the College of Notre Dame awarded its first bachelor's degrees, Mother Theophila Bauer applied to Rev. Thomas Conaty, rector of the Catholic University of 
America in Washington, for official affiliation with the university: "Recognizing the Catholic university as the culmination of the Catholic educational system of America, ... the Faculty of Notre Dame of Maryland respectfully ask of the University the same measure of recognition accorded to Colleges for men, that have fulfilled such conditions as are prescribed for affiliation." 10 Taken aback by this request, the university trustees discussed the matter two days later. Although the liberal bishops John Ireland of Saint Paul and John Lancaster Spalding of Peoria supported Bauer's request, Cardinal Gibbons adamantly opposed it. He insisted that the distinction of being the first female college to affiliate with Catholic University rightfully belonged to the projected Trinity College, "not only because of its proximity to the University, but also because of the sacrifices entailed in its founding." ${ }^{11}$ Although the board rejected the College of Notre Dame's application, it formed an ad hoc committee of Conaty, Spalding, and Archbishop John J. Keane to explore "the matter of affiliation of female colleges and academies." 12

In June 1900, the committee asked College of Notre Dame administrators for "a complete statement of your Collegiate work as leading to the A.B. degree." ${ }^{13}$ Dean Meletia Foley seized this opportunity to press her views on the right of women to higher education on equal terms with men. In a remarkable document, she pointed to the successful affiliation of secular women's colleges with universities in England and the United States. ${ }^{14}$ At Radcliffe College, she wrote, "the requirements for the degrees of Bachelor of Arts and Master of Arts [were] . . . the same as for the corresponding degrees in Harvard University." Barnard College women received a degree "of equal value with the degree of B.A." awarded Columbia University men. She concluded her case by quoting Saint Peter Fourier: "The elevation of a whole people is possible only through its women." ${ }^{15}$ Despite its logic and eloquence, the letter did not sway the university's trustees. At their October 10, 1900, meeting, they denied affiliation to any women's college, "considering what it means and what it may imply." 16 Over the next few years, the university published requirements for colleges seeking affiliation, and "duly affiliated" three colleges, all female institutions. ${ }^{17}$ Notre Dame, however, did not gain university affiliation for another decade, probably due to its persistently small size.

Much about the higher-education landscape had changed between 1899 and 1969, but men's institutions' reflexive sense that women's institutions existed only on sufferance had not. As a result, smaller and poorer Catholic women's colleges tended to catch the brunt of the fallout from decisions made by their all-male neighbors in the face of their own late-1960s enrollment crises. The experiences of the College of Notre Dame with its 
neighbor, a Catholic men's college, were representative. ${ }^{18}$ The Jesuits, who established Loyola College in 1852 in downtown Baltimore, relocated their school in 1921 to property immediately adjacent to Notre Dame's campus. When Loyola opened its doors to women in 1971, the College of Notre Dame faced formidable challenges to its autonomy and long-term survival. The interaction of the School Sisters of Notre Dame and the Jesuits as they addressed the coeducation question provides exceptional insight into the gender dynamics of Catholic higher education in twentieth-century America.

In the 1920s and 1930s, the Jesuits took pains to distinguish themselves from the female institution next door. Even though the colleges were of comparable size in the 1930s, the Jesuits conveyed an attitude of male ascendancy in their dealings with the School Sisters of Notre Dame and their students. ${ }^{19}$ In particular, they avoided the slightest hint of "coeducation." A testy exchange between the college presidents in 1928 concerning an advertisement placed by the College of Notre Dame in magazines and newspapers is revelatory. The notice described the college as "taught by the Sisters of Notre Dame and assisted by the Fathers of Loyola College." Loyola's president, Henri Wiesel, SJ, immediately protested to Notre Dame's president, Mother Philemon Doyle. The content of the advertisement was accurate, he conceded, but it gave the impression that Loyola's Jesuits were teaching "young girls," his term for Notre Dame students.

Wlodimir Ledochowski, SJ, superior general of the Jesuits at this time, adamantly opposed any form of coeducation in the order's schools, and Wiesel felt sure that he would not be pleased to hear that Jesuits were teaching women in Baltimore. "I am not going to be so sudden in action as to withdraw the Fathers," he told Doyle, "but I am going to ask that such advertising make no mention about the Jesuit Fathers being on the Faculty." ${ }^{\prime 20}$ Wiesel made his views on women's education clear in the baccalaureate sermon he preached at Notre Dame in 1933 when he advised the graduates to "Learn the humble arts of cooking and sewing and mending," and "assume the responsibilities of child-bearing and child-rearing." ${ }^{21}$ His attitude, as we have seen, was shared by many of his contemporaries.

Catholic undergraduate colleges, with few exceptions, remained singlesex institutions for many decades. Bishops and clergy particularly discouraged parents from enrolling their daughters in highly respected Protestant women's colleges. Catholic women's colleges offered special religious as well as academic and social benefits. Like his counterparts across the country, Rev. Martin Gamber, chaplain of the Notre Dame preparatory school, warned 
students in the 1940s, "You can't go to Vassar, you'll lose your religion." 22 As the number of middle-class Catholic youth eager to attend college rose swiftly in the twentieth century, bishops and clergy across the country reiterated the dangers of coeducation. While some Protestant churches, Barbara Solomon notes, "justified coeducation in ethical and religious terms of the equality of souls, male and female," the Catholic Church continued to maintain that mingling the sexes at the undergraduate college level posed moral dangers that outweighed any social benefits of gender equality. ${ }^{23}$

Nonetheless, the subject of coeducation remained important in Catholic educational circles. By the early 1900s, states were developing certification requirements for teachers at private as well as public schools, and parochial schools had to meet these state standards quickly. Catholic women's colleges were still few in number and scattered geographically. Some local bishops turned to the men's colleges in their dioceses for a solution. In 1909, Marquette University in Milwaukee set a precedent by introducing a summer program to prepare parochial school teachers on a part-time basis for state teaching certification. According to a contemporary report, the Milwaukee Jesuits, who conducted Marquette, took the step "only after persistent urging of the Ordinary, Archbishop Messmer." ${ }^{24}$

Marquette's 1912 summer school rules for nuns were strict. According to Pauline M. A. Tavardian, they could "sit in class, but they were not permitted to recite. Because Jesuits were not permitted to teach women, weekly papers and exams had to substitute for classroom participation. ${ }^{25}$ Bishops nationally called on male religious orders that conducted colleges within their dioceses to launch similar part-time programs for parochial school faculties. Through "female programs," offered via part-time extension, evening, and summer courses, full-time teachers earned state certification. ${ }^{26}$ By 1916, Marquette's evening and summer programs enrolled several hundred women, lay as well as religious sisters. None attended classes in the regular full-time college, which remained a male preserve.

An early exception to the strict single-sex policy that marked Catholic higher education occurred in the 1910s and 1920s. In 1891, Mother Katharine M. Drexel, heir to a large Philadelphia banking fortune, founded the Sisters of the Blessed Sacrament, a religious order devoted solely to the education of African Americans and Native Americans. Since no Catholic college in the nation, male or female, admitted African American students, Drexel determined to remedy that situation. In 1917, she expanded a New Orleans high school for girls that she had founded two years earlier into a teacher training school. She then proceeded to gain papal permission for religious sisters 
to teach male students at the college level and, with the members of her sisterhood, gradually developed the training school into a state-accredited, four-year Catholic liberal arts college. When Xavier College awarded its first bachelor's degrees in 1928, it became the nation's first Catholic college to admit African Americans and its first Catholic coeducational college. ${ }^{27}$

As young men entered military service during World War I, a sharp dip in college applicants brought the coeducation question to the fore in Catholic men's college circles. But since the enrollment impact of this war was short lived, 90 percent of Catholic colleges were still single-sex in the early 1940s. (The figure was about 30 percent for all US colleges.) When enrollments in men's colleges again plunged following the nation's entry into World War II, administrators at Catholic men's colleges prepared to make a case for coeducation with the national hierarchy. However, the passage of the Servicemen's Readjustment Act of 1944 (the GI Bill), which provided tuition and monthly stipends that enabled returning veterans to attend colleges and technical schools, addressed their enrollment concerns. Applications to Catholic men's colleges soared, and trustees and administrators responded by expanding faculties, academic and housing facilities, and campus real estate. "Overall in 1947," according to Elizabeth A. Edmondson, "Catholic schools reported enrollment increases ranging from 50 percent to more than 200 percent over prewar enrollment." 28

Baltimore's Loyola College, like other men's colleges in the postwar era, was very eager to expand its enrollment. However, it was extremely land poor. Rev. Vincent Beatty, SJ, who became president of the college in 1955, saw in the campus of the College of Notre Dame next door an expedient solution to this problem. ${ }^{29}$ In 1957, he approached Sister Matrona Dougherty, superior of the Notre Dame community and a member of the college's board of directors, to discuss his "property problem." He explained that he wanted to acquire a piece of land owned by Johns Hopkins University that lay between the Notre Dame and Loyola campuses. But at this time, Johns Hopkins did not wish to sell it. Beatty believed that Johns Hopkins very much wanted to acquire "a strip of Notre Dame property." If Notre Dame would sell this piece of land to Loyola, he would then proceed to offer it to Johns Hopkins in exchange for the Hopkins parcel he particularly wanted. Dougherty informed him that Notre Dame's board of directors had "decided not to sell any of our land." ${ }^{30}$

As the applicant pool of returning veterans declined in the 1950s and early 1960s, men's colleges, left with underutilized faculties and facilities, saw in coeducation a good strategy for survival and growth. At this time, all women's colleges were facing serious enrollment concerns as female 
high school graduates opted in rising numbers for coeducational colleges. A move to coeducation by Catholic men's colleges would pose a particularly severe challenge to the nation's 116 small Catholic women's colleges. In 1951, presidents and deans from sixty-six of these institutions attended a "special conference on the problems of women's colleges" convened by the National Catholic Educational Association. Their overriding concern was the prospective move to coeducation by Catholic men's colleges. ${ }^{31}$ The long-standing policy of single-sex education at Catholic undergraduate colleges had long protected women's institutions from having to compete for students with the typically larger and richer men's colleges located near them. Although the Loyola and Notre Dame campuses had existed in close proximity since 1921, Notre Dame did little active recruiting. According to an early director of admissions, "We didn't go out and look for students; we just waited for them to come. We seemed to have enough at the time." ${ }^{32}$

This casual approach marked many Catholic women's colleges until the church's traditional opposition to coeducation evaporated in the postwar years. Leaders of men's colleges, by this time, had gained considerable support from the national church hierarchy. At the 1952 meeting of the National Catholic Educational Association, Archbishop Richard J. Cushing of Boston spoke for most of the church hierarchy when he announced that "coeducation is here to stay and there is nothing we can do about it." Instead of "bickering about the threat of coeducation to women's colleges," he said, Catholic colleges ought to be working to enroll the " 60 percent of the Catholic student potential" currently attending secular institutions. ${ }^{33}$

Despite male impatience, women's college leaders raised the coeducation question again at the 1954 annual meeting of the National Catholic Educational Association. They noted that since Catholic colleges in the United States had been single-sex since the founding of Georgetown College in 1789 , churchmen who advocated that these institutions shift to coeducation were dishonoring a 165-year tradition. This was too much for Rev. Edward Rooney, SJ, executive director of the Jesuit Educational Association, who dismissed this observation out of hand. The "Catholic tradition" of single-sex colleges was a fiction, he argued. The Catholic Church had never opposed coeducation. "Are we going against tradition in having coeducation in higher education?" he said. "I do not think you can talk about tradition in the education of women on the higher-level." ${ }^{34}$

Coeducational colleges were steadily attracting more female applicants, and leading mainstream men's colleges were debating whether to open their doors to women. ${ }^{35}$ Catholic men's institutions recognized that if they did not follow suit, they would likely close. Once they had the green light from the 
national hierarchy and from leaders of male religious orders, these institutions began to take action in the 1960s. Many dioceses had at least one college for men and another for women. Larger urban archdioceses had more. Male colleges in these locations typically commenced their shift to coeducational status by seeking to merge with nearby women's campuses. If successful, they could boost their applicant pools virtually overnight and simultaneously acquire desirable real estate. Women's colleges refusing to merge would see their enrollments fall.

In Baltimore, Loyola president Vincent Beatty's aggressive campaign for land aroused concern that Loyola might have further designs on the College of Notre Dame's campus. Thus college leaders viewed with considerable ambivalence his 1964 proposal that the two colleges build a joint library. At this time, Notre Dame's Fourier Library, constructed in 1941, was judged adequate for the college's future needs. However, lack of funds had slowed development of its book collection, and in the 1960s, the collection ranked below American Library Association standards for a college of Notre Dame's size. ${ }^{36}$ Some trustees viewed a joint library as a good solution to Notre Dame's library accreditation difficulties. ${ }^{37}$ Provincial Superior Mother Vitalia Arnold, who chaired the board of trustees, worried about the financial implications of the library proposal. She urged the trustees to "reserve your judgement" until the completion of the new science building. Despite some concern that delay could mean the loss of a golden opportunity, the board agreed to withhold its approval until "a plan for the financing of a joint library can be developed which Notre Dame can handle." ${ }^{38}$

Impatient to move the library proposal forward, Notre Dame trustee Henry Knott appealed to Baltimore archbishop Lawrence Shehan for assistance. "We have run into a road-block here with Mother Vitalia," he told Shehan, "so I had Sister Margaret Mary O'Connell at the College call their Mother General (Ambrosia [Roecklein]), who happened to be in the United States, and discuss this with her, and ask her to tell the Mother [Vitalia] that you had told me you were in favor of this project." Shehan agreed to "prevail upon her to let the project proceed." 39 At a meeting with Mother Ambrosia, he argued that Notre Dame ought to put Fourier Library to another use and cooperate with Loyola on the joint library project: "The project has my whole-hearted approval," he said. ${ }^{40}$

Notre Dame's trustees approved the library project in 1966. The officers of the Loyola-Notre Dame Library Corporation were Truman Semans of Loyola (president) and Sister Mary Ian Stewart of Notre Dame (vice president). As part of its share of the project's estimated $\$ 5$ million cost, Notre Dame agreed to contribute 4.6 acres of land bordering Loyola's campus 
as the site for the joint library. ${ }^{41}$ Progress was slow for several years. Just as negotiations were about to be finalized, Loyola officially announced that it would begin to admit women in September $1971 .{ }^{42}$ At this news, Notre Dame's trustees considered abandoning the cooperative library project, but "after tense discussion [with Loyola] . . . the decision to continue was affirmed." ${ }^{43}$ When the Loyola Notre Dame Library opened in 1973, with expenses prorated according to institutional enrollments, it was the nation's only library built and jointly owned by two institutions of higher education. ${ }^{44}$

Relations between the two colleges had been deteriorating rapidly for nearly a decade when, in the early 1960s, the College of Notre Dame, Loyola College, and Mount Saint Agnes College, a women's institution in straitened financial circumstances, set up a narrowly focused "joint committee on cooperation to work toward internship collaboration." The group met routinely until 1967, when the Mount Saint Agnes committee member called for "a complete merger" of the three colleges. The idea stunned Notre Dame trustees. ${ }^{45}$ With the exception of the joint library project, the colleges had always operated independently. Realizing that the term "merger" was a red flag for Notre Dame, Loyola officials thereafter referred to "federation." But for their Notre Dame counterparts, the terms were synonymous. The battle lines were drawn.

In March 1968, Loyola and Mount Saint Agnes proposed that the three colleges jointly petition the Association of Colleges and Secondary Schools of the Middle States and Maryland for a common evaluation at its scheduled 1970 reaccreditation visit. Notre Dame refused to join in the request. A few months later, Loyola and Mount Saint Agnes received a \$100,000 grant from the US Department of Health, Education, and Welfare "to study the feasibility of merging their curricula and perhaps their administration." ${ }^{46}$

Like many men's colleges contemplating a move to coeducation, Loyola needed to acquire real estate and financial resources. With nearby Notre Dame and Mount Saint Agnes, it developed a "cooperation committee" that aimed to expand interinstitutional programs ${ }^{47}$ In March of 1970, a TriCollege Study Committee recommended that "the three colleges be federated by September 1971,"48 and a month later, Loyola trustees unanimously resolved "to [join] our two sister institutions . . . in a federation." ${ }^{49}$ Loyola also pledged to seek "the proper formula for the final federation of the three colleges." ${ }^{50}$ By this time, rumors of a possible merger were spreading on the Notre Dame campus, but since high-level negotiations were as yet confidential, the atmosphere remained relatively calm. This ended in early June 1970 when Notre Dame's acting president, Sister Elissa McGuire, remarked at an 
alumnae event that a merger of Notre Dame and Loyola was a distinct possibility and that it "might be found more beneficial than simple cooperation." ${ }^{1}$ The comment spread like wildfire.

These rapid developments alarmed Notre Dame's trustees and administrators. They commissioned Sister Kathleen Feeley, then a faculty member in the English Department, to draft a position paper detailing the college's position for use in future discussions with the other two institutions. She was particularly to indicate areas where Notre Dame might cooperate with Loyola and Mount Saint Agnes and specify areas that would be nonnegotiable. ${ }^{52}$ On June 12, 1970, Mother Maurice Kelly, Acting President Elissa McGuire, and trustee George Constable met with representatives from Loyola and Mount Saint Agnes, and with Baltimore's Cardinal Lawrence Shehan, to discuss a possible merger of the institutions. The cardinal strongly favored the concept. Notre Dame's representatives, however, stated that Notre Dame would participate in coinstitutional programs but would not merge with Loyola and Mount Saint Agnes.

At the next meeting of Notre Dame's board of trustees, Henry Knott, an alumnus of Loyola and, concurrently, a trustee at both Loyola and Notre Dame, proposed that Notre Dame accept the merger proposal. The crucial consideration, in his view, was "what was best for Catholic higher education in Baltimore, not what was best for any individual college." ${ }^{33}$ His fellow trustees, a majority of whom were sisters, overwhelmingly disagreed with his suggestion, and proceeded to ratify Feeley's position paper as Notre Dame's official Ten-Point Federation Plan. Its key points were that Notre Dame would agree to federation on two conditions: that the federated colleges would "continue with separate names, charters, boards of trustees, student bodies, and degrees," and that Notre Dame, in addition, would "continue with its separate administration, faculty, campus, girls' residence halls, and student government." ${ }^{54}$

Sentiment on the merger question within Notre Dame constituencies was solidly with the board of trustees. As part of its seventy-fifth anniversary celebration, Notre Dame convened a campus-wide conference (Quest '70) to consider the direction of the college over the next decade. However, Loyola's stunning merger proposal took center stage in the day's discussions. Attendance was very high, and George Constable confirmed that "all present at the program were opposed to [the] merger." 55 Mount Saint Agnes College, in significant financial difficulty, merged with Loyola on July 1, 1971. ${ }^{56}$ History professor Charles Ritter recalled that Mount Saint Agnes's swift "absorption" by Loyola seemed to Notre Dame constituencies "a portent of what would happen to us if we 'merged' with Loyola." ${ }^{57}$ 
As in the 1950s, meanwhile, a shortage of land soon thwarted Loyola's ability to admit a substantial number of women while maintaining its desired male enrollment. Like Father Vincent Beatty, whom he succeeded in 1964, Loyola's president, Joseph Sellinger, SJ, saw in the Notre Dame campus next door an ideal solution to his space constraints. Notre Dame's lush sixty-twoacre campus included five residential buildings; four educational, administration, and library buildings; and four utility buildings. ${ }^{58}$ Aware that Notre Dame's residence halls were underutilized, due in part to his own institution's recent move to coeducation, in 1973 Father Sellinger requested that Notre Dame rent dormitory space to house Loyola's female undergraduates. The college refused to consider this proposal. ${ }^{59}$ Despite troubling enrollment and financial projections, Notre Dame trustees stood united when Sellinger returned two years later asking to purchase ten acres of Notre Dame's campus to use for Loyola's female sports programs. He also sought to lease a section of Notre Dame's new Knott Science Center or, alternatively, to append a "Loyola wing" to that building. ${ }^{60}$ Again, Notre Dame's trustees dismissed these proposals. ${ }^{61}$

In 1975, Loyola suggested the formation of a joint Loyola-Notre Dame Committee to promote institutional cooperation "free from past experience." ${ }^{\prime 2}$ Notre Dame's trustees formed an ad hoc committee to assess the proposal. While this group was deliberating, several prominent local citizens, among them the archbishop, again lobbied Notre Dame to sell land to Loyola. In a flurry of heated speeches and press releases, they accused Notre Dame of being behind the times and indifferent to the common interests of Catholic higher education in Baltimore. Notre Dame administrators and faculty resolved not to bend to "this kind of influence." ${ }^{33}$ In its report to the board of trustees, the ad hoc committee maintained that Loyola's cooperation proposal was just another strategy in its campaign for land: "To sell or lease one of our basic assets to a competitor is simply to impede our possible growth and to extend Loyola's long arm around the edge of our campus, indeed into it. . . The college should . . say that the answer is "no." 64 In February 1976, with one abstention, the board of trustees voted not to sell or lease any land to Loyola. An overwhelming majority of the wider campus community backed that decision.

Loyola's interest in Notre Dame's land remained high, however. In late October 1977, Henry Knott, now a former Notre Dame trustee, took up Loyola's cause. He apprised President Kathleen Feeley that a major Loyola benefactor was willing to pay $\$ 500,000$ for ten acres that Loyola desired "in the rear of your property, adjacent to the library." In his opinion, this was a superb opportunity for Notre Dame to acquire badly needed funds. Again 
the college's trustees declined the offer. "It would be folly for Notre Dame to diminish its campus," Feeley informed Knott. "The sisters who bought this property in 1873 had much more land than they 'needed'; yet over the years the development of the College has led to the constructive use of almost all of its acreage. The present administrators should be equally farsighted." 65 Undeterred, Knott sent Feeley the proposal to purchase land for Loyola and requested her "considered judgment on same." ${ }^{\circ 6}$ Again Notre Dame refused to sell any land to Loyola. ${ }^{67}$

President Sellinger, however, would not take no for an answer. Late in 1978, with no progress in sight, he made a dramatic public statement to the Baltimore press, Loyola alumni, and the wider Maryland Catholic community. Despite his best efforts, he announced, he had failed to acquire any land for Loyola by purchase or lease. As a result, Loyola's future was in jeopardy. As it was no secret that Sellinger wanted property owned by the College of Notre Dame, his remarks turned public sympathy against the women's college. Kathleen Feeley responded firmly, reminding Sellinger that when Loyola made the decision to become a coeducational college seven years earlier, it was well aware that it would need more real estate to expand its academic facilities, student housing, and athletic fields. It also knew that the College of Notre Dame intended "to plan its future as an independent women's college ... [and] not to diminish its campus by selling or leasing acreage." Therefore, to suggest that "whoever did not sell or lease land to Loyola is responsible for its land shortage" was preposterous. She concluded that "with Robert Frost I believe 'good fences make good neighbors." 68 Tensions between the colleges eased somewhat thereafter, but Notre Dame remained vigilant. ${ }^{69}$ As George Constable recalled in 1989, Loyola was always "desperate for land. . . There was great pressure for us to either sell them land, or give them land, or lease them land, which we resisted. That went on for many years, and I guess is still going on, in a sense."70

In the 1960s and 1970s, Loyola's Jesuit leaders showed little sympathy for Notre Dame's decision to maintain its status as an independent women's institution. In their view, coeducation was both inevitable and desirable for Loyola, and annexing Notre Dame was a logical way to achieve that goal. The School Sisters of Notre Dame absolutely disagreed. Without doubt, the coeducation battle of the 1960s and 1970s was the greatest challenge in the history of the College of Notre Dame. It also had lasting benefits. As one faculty member of the era put it, "We came to a better sense of ourselves as unique, also a sense of ourselves as performing a service, the service of education, for people in a way which was necessary, useful, and which would not have continued had we merged." ${ }^{\prime \prime 1}$ In the half century since, relations 
between the two institutions and their sponsoring religious communities have become increasingly collegial. Today, their students freely crossregister, and schools and programs of Loyola University Maryland and Notre Dame of Maryland University are coeducational, with one exception: the undergraduate women's college of Notre Dame of Maryland University. ${ }^{72}$

\section{Growing Professional Programs}

The decision of the College of Notre Dame to remain a single-sex institution was countercultural in the 1970s. Popular sentiment was that Catholic women's colleges could not successfully compete with church-affiliated coeducational institutions. From exclusion to courtship to takeover was the common experience of most women's colleges in their interaction with formerly male institutions in their locales. The few that succeeded in remaining women's colleges, like Notre Dame, did so by identifying new student populations and taking bold steps to accommodate their needs. ${ }^{73}$

The College of Notre Dame's trustees had elected Sister Kathleen Feeley as president in 1971, the same year that Loyola began to admit women students. Feeley faced severe challenges. Over the previous five years, full-time enrollment had declined by 30 percent, to 549 students. ${ }^{74}$ A study undertaken for the Maryland Council for Higher Education and the Maryland legislature, as well as audits for 1967-68 and 1971-72, revealed a "financially insecure" institution. At this time, over half the college's educational and general revenue was coming from the sisters' contributed services $(\$ 376,000)$ and a Maryland state grant of $\$ 90,000$, and endowment income accounted for only 1 percent of total revenue. ${ }^{75}$ The college was financially unstable and in debt, and the contributed services of the sisters were beginning a sharp decline. ${ }^{76}$ Most critical, the college's enrollment prospects were bleak. Over the years 1967-72, revenue from tuition and fees had declined by 6 percent while expenditures had increased by 21 percent. The study projected that expenditures would rise by 6 percent annually and considered the $\$ 2.2$ million debt outstanding on Doyle Hall and the Knott Science Center to be very high, given the college's contingent liability for the joint library.

Based on a projected total enrollment of six hundred and annual tuition and fees set at $\$ 1,600$, the college faced a $\$ 380,000$ deficit by $1976-77 .{ }^{77}$ To avoid such a shortfall, and in the absence of other income, tuition and fees would have to rise by 10 percent annually. With enrollment declining, this was not an option. Feeley informed the trustees that if they would hold tuition and fees at \$1,600 until 1976-77, she believed she could raise enrollment 
to 896 full-time equivalent students by that date. If successful, this strategy would produce a $\$ 94,000$ budget surplus by that year. The trustees, with no other options, approved Feeley's proposal, although they considered her enrollment projection overly optimistic. ${ }^{78}$

Feeley saw in the introduction of innovative professional programs a promising solution to Notre Dame's survival as a women's college. Trustees, administrators, and faculty joined forces to develop the Weekend College, as recounted in chapter 4 . The Weekend College became the leading factor in improving the college's financial and enrollment positions. By 1986-87, enrollment was nearly 40 percent higher than it had been a decade earlier. ${ }^{79}$ Registration in the Weekend College was 953; in master's degree programs, 183; and in the regular undergraduate college, 753. By 2002, the Weekend College enrolled 2,400 students. The college's operating budget was in the black, and its endowment was slowly growing. Notre Dame students were cross-registering at six local institutions, including Johns Hopkins and Loyola. ${ }^{80}$ The 1987 U.S. News \& World Report survey ranked the College of Notre Dame fourth among smaller comprehensive institutions in the East. ${ }^{81}$

The Weekend College had emerged from an effort to meet a specific crisis: how to remain independent and female in competition with Notre Dame's neighbor, Loyola College. But its success had other positive effects, and they brought the institution badly needed publicity. "People started hearing Notre Dame, Notre Dame. ... It lost some of its image that it had before of being exclusive. ... We knew we had to do it on our own, we had to make Notre Dame someplace where young women wanted to go," recalled Sr. Dorothy Arthur, the college treasurer from $1969-75 .{ }^{82}$ As the college became more visible and accessible to local women in the 1970s, it exerted a growing influence within the Baltimore community. It also saw rapid diversification of its student body. Although the college had admitted its first African American student in 1951, the number of minority students did not increase markedly for two decades. By 1984, however, African Americans constituted 11 percent of the student body ${ }^{83}$ A 2000 analysis of the percentage of black students at fifty-two women's colleges listed the College of Notre Dame in eleventh place, with 17.2 percent. Among eighteen Catholic colleges in the survey, Notre Dame ranked fourth. ${ }^{84}$ By 2014, nearly one-fourth of its total enrollment was African American.

By most measures the Weekend College was a major success, both serving new populations of students and enabling the institution to stay afloat. In 1987 Feeley described it as "a unique mode of delivering education to a working population.... With 717 graduates and 953 students in its undergraduate 
degree programs and 183 students in its master's degree programs, the Weekend College has proved itself to be an educational service which has, indeed, 'made a difference' in metropolitan Baltimore and beyond. . . In Notre Dame's Weekend College, the part-time student has been elevated to first-class status. . . Notre Dame offers [them] all the support systems and amenities which one usually finds only in a full-time program." ${ }^{85}$ But not everyone shared Feeley's enthusiasm about these developments. While the Weekend College enrollment had climbed notably, that of the day college had not, stagnating at about 800 by the turn of the twenty-first century. In fact, the regular undergraduate college enrollment in 1970 was higher than it was in $1983 .^{86}$

As a result of these changes, the pattern of majors of Notre Dame students in the 1980s differed considerably from what it had been three decades earlier. Professional fields of study continued to increase in popularity at Notre Dame and other educational institutions nationally during the next few decades. ${ }^{87}$ Although a five-year pre-engineering program allowed students to earn BA degrees from Notre Dame and BS degrees from the University of Maryland College of Engineering, ${ }^{88}$ the college's long-standing emphasis on science was under siege. The formerly strong English and foreign language departments together enrolled only 6.3 percent of student majors in 1984, whereas communications attracted 16.5 percent. Three professionally oriented fields accounted for nearly half (47.1 percent) of all majors. As the college prepared for university status in 2011, it sought and received the approval of the Maryland Higher Education Commission for new undergraduate majors in nursing, marketing communications, international business, and environmental sustainability. ${ }^{89}$ Faculty debated how Notre Dame could continue to be a quality liberal arts college when it enrolled a majority of its students in professional, career-focused programs. To meet this concern, general education requirements in the liberal arts increased between 1970 and $1990 . .^{90}$ But ensuring that degrees earned via part-time programs equaled in quality those awarded in the full-time undergraduate women's college remained an ongoing concern.

\section{Catholic Identity on Campus, 1970s-2000s}

Catholic higher education for women developed in a century marked by momentous political and economic change and evolving social mores. Suffrage, a prolonged depression, and two world wars had widened women's professional ambitions and social independence; the civil rights and feminist movements mobilized women to demand equal opportunity with men in 
education and employment; and the Second Vatican Council of the 1960s motivated Catholic women's colleges to reassess their institutional identities. The College of Notre Dame of Maryland was a pioneer in the late twentieth-century movement to broaden the accepted definition of American collegians. No longer were they a demographic cohort of eighteen-totwenty-one-year-olds who earned bachelor's degrees over four years of full-time study. Now their ranks included employed adults who enrolled on a part-time basis and took more than four years to earn their degrees. As a result, the 1970s saw increasing racial, ethnic, and religious diversity among faculty and students. The proportion of Catholic students and faculty at Notre Dame declined, as did the visibility of the religious order on campus. At the same time, the institution's local influence was rising as it enrolled relatively more students from greater Baltimore and the surrounding communities. Such changes raised several essential questions for a college seeking to witness to its religious identity and historic mission in American society.

The Collegiate Institute (1873-95) and, subsequently, the College of Notre Dame had enrolled Protestant and occasionally Jewish students. Catalogs made it clear that the college welcomed students of any or no religious faith, until an amended version appeared in 1921-22, stating that "students of Christian denominations are received." "91 Until the 1970s, despite early experiences with religious diversity, a largely Catholic student body and faculty shared perspectives about the religious identity and mission of the college. The court cases of the 1960s and 1970s discussed in chapter 5, however, caused significant change. Usually, historical treatment of church-state conflicts focuses on the state- that is, on the implications of aid to a churchrelated institution for the wider society - and not on the aftermath of a success or failure in a court challenge for the church-affiliated institution. The College of Notre Dame's experiences in the church-state cases reveal how mainstream challenges affected the direction of Catholic higher education for women.

The court cases had demonstrated that Notre Dame was a public as well as a church-related institution. The fear of more court tests of "pervasive sectarianism" caused some reluctance to state the college's strong ties to the Catholic Church. Adapting to this new reality caused uneasiness on campus. The purpose of the college was "to bring about intellectual growth in the student, based on Christian principles," declared Sister Virgina Geiger. "Once we have not fulfilled that I don't see any reason for us existing."92 But while most members of the college community agreed that religion was central to the life of the college, it had become very clear not only that the college 
needed to broaden its ecumenical appeal, but also that its traditional ways of witnessing to Catholicism's importance on campus had become ineffective even to many Catholic students. By the 1980s, student involvement in college religious services and activities had considerably diminished. The Campus Service Organization, to which all students belonged, had no religious element. Many students were indifferent to the college's religious affiliation; some opposed publicizing it. In 1986, for example, Columns editors expressed misgivings "about the religious trend [that] an issue on Mother Teresa [of Calcutta] would indicate." ${ }^{93}$ More than half the students surveyed at this time could not evaluate campus ministry programs because they did not feel familiar enough with them to do so. ${ }^{94}$

It was not only the wake of the Horace Mann and Roemer cases, then, that made the college, like many of its peers, become a more secular institution. As faculties and student bodies became more religiously diverse, institutions had to reassess how best to interpret and witness to their traditional religious missions. Notre Dame's official mission statements, published in its annual catalogs, attest to its struggle with this issue in the 1970s and 1980s. In 1974-76, "Judeo-Christian" replaced "Catholic" in a statement expressing the institution's commitment to "those beliefs upon which the college was founded: the belief in Judeo-Christian values; the belief in the value of women; and the belief in the value of education." 95 The word "Catholic" reappeared in the 1982-83 catalog statement, but only in a general sense: "The College of Notre Dame was inspired by and exists today in the Catholic tradition. ${ }^{.96}$ According to the $1984-85$ catalog, the education offered "is values-oriented, an education that emphasizes the total development of the student—spiritual and moral as well as intellectual." ${ }^{\prime 97}$

Notre Dame's 1986-87 catalog acknowledged the institution's allegiance to its founding principles, including "a conviction in the value of a quality liberal arts curriculum, a dedication to the education of women, and a belief in Judeo-Christian values." ${ }^{.98}$ That year, there was considerable campus discussion about whether or not "Judeo-Christian" was a "more inclusive" term than "Catholic,"99 and the Middle States Association's evaluating team suggested that the mission statement incorporate a fuller explanation of the meaning of the term "Judeo-Christian values." ${ }^{100}$ In her response, President Feeley emphasized that at Notre Dame,

the Catholic educational tradition has provided a firm base on which to build a philosophy, a curriculum and a spirit of service. ... To foster a holistic education, we give attention to the spiritual life as well as to the intellectual life.... We support traditional religious values.... The 
cross which tops the Merrick Tower of Gibbons Hall is visible from miles around the college. It signals to one and all the spiritual dimension of life and the spiritual dimension of a Notre Dame education.... It is a spirituality which excludes no one.... Whether muffled or clear, this spiritual note enriches the educational milieu of Baltimore." 101

In her reply, Feeley situated a broadly appealing "spirituality" in the context of the College of Notre Dame's Catholic heritage without delineating theological or practical expectations for students and faculty. This was perhaps a necessity, because the identity of both groups was rapidly changing. Much of the burden for providing a Catholic campus environment for faculty as well as students had traditionally rested on the sisters, recalled a lay faculty member: "The sisters always have ... provided both the spiritual background for what takes place in the education process here at the college, and also a very serious and devoted academic dedication which they transmit to the students and also to the lay faculty." 102

The college's religious character was becoming a growing concern as the sisters' visibility on campus declined. A sustained national slump in the popularity of single-sex colleges had tested the staying power of American women's colleges in the 1970s and beyond. At the same time, a second viability challenge for Catholic institutions came from a sustained downward spiral in the number of young Catholic women joining the religious orders. Whereas these groups nationally reported a total of 32,433 candidates between 1958 and 1962 , the corresponding total for $1971-75$ was only $2,590 .{ }^{103}$ This slump severely affected the capacity of sisterhoods to support the colleges they had founded.

Until this era, the sisters' services had spared Catholic women's colleges undue concern about a key budget item. Sisters on their faculties subsidized the college by working for minimal salaries. Their contributed services reduced the need to hire costlier lay faculty. As late as the 1960 s, Notre Dame president Margaret Mary O'Connell casually requested that the order educate more sisters for the college faculty, proposing that superiors assign six junior sisters annually to earn $\mathrm{PhDs}$. She reasoned that "the dividends for both College and Community, most of whose Sisters received their first undergraduate degree at this College, would far exceed the costs in personnel, time and money, over the long haul." ${ }^{104}$ But such recommendations came too late.

The proportion of sisters holding full-time faculty and administrative positions at Notre Dame had held steady in the midcentury decades, at 58 percent in 1940 and 61 percent in $1960 .{ }^{105}$ By 1987, however, of a total 
full-time faculty of sixty-six, School Sisters of Notre Dame accounted for only one-third. ${ }^{106}$ Some colleges experienced far steeper declines. Between 1960 and 1980, the proportion of Sisters of Mercy on Chicago's Saint Xavier's College faculty dropped from 60 to 10 percent. ${ }^{107}$ This falloff had an immediate effect on institutional budgets. At Notre Dame, the donated services of sisters accounted for 27 percent of total institutional income in 1956, but only 20 percent in $1971 .{ }^{108}$ In 1978 , Feeley, noting that "at present religious comprise $52 \%$ of the faculty," invoked anxiety about the college's financial position: "We have always considered the contributed services of the SSNDs to be our 'living endowment.' In recent years those services were the equivalent of the income from approximately $\$ 9.5$ million. However, decreasing numbers of religious in our society means that we must look to the day when a greater portion of our faculty will be lay teachers." 109

On March 19, 1992, the Notre Dame board of trustees elected one of their membership, the trustee and executive vice president Rosemarie Nassif, SSND, to succeed Kathleen Feeley as president of the college. ${ }^{110}$ The new president's grace period was short. Feeley's success in addressing the challenges of coeducation and college finances had led many to consider her the savior of the college. At the same time, difficult battles for tenure, higher salaries, and participation in college governance decisions during her term of office had produced a faculty, sisters and lay alike, that was vigilant about its hard-won rights. Feeley was able to introduce the Weekend College in the 1970s quickly, and with minimal faculty involvement, because it was evident to all constituencies that the college's survival required immediate action. In the early 1990s, however, no comparable threat to institutional survival loomed, and both religious and lay faculty members had begun to play significant roles in college governance. ${ }^{111}$

Nassif's strategic plan included several ambitious initiatives that soon generated campus controversy. Faculty apprehension focused on her proposal to replace the college's traditional organizational structure with a fivevice-president model. While this was a common configuration among peer institutions, faculty questioned its usefulness for a college of Notre Dame's size. They called for more consultation about a restructuring that could adversely affect their authority in college governance. Campus tensions rose in 1995, and in February 1996, Nassif resigned. ${ }^{112}$ Dorothy Brown, professor of history at Georgetown University, served as interim president during 1996-97. ${ }^{113}$ In the spring of 1997, Mary Pat Seurkamp, vice president for institutional planning and research at Saint John Fisher College (Rochester, New York), became the first lay president of the College of Notre Dame, an office she held until her retirement in 2012. Following the 2013 resignation of President 
James Conneely, formerly associate provost at Eastern Kentucky University, Joan Develin Cooley, president emerita of McDaniel College (Westminster, Maryland), served as interim president of the college until 2014. That year, the board of trustees elected Marylou Yam, provost and vice president for academic affairs at Saint Peter's College (Jersey City, New Jersey), as president of Notre Dame of Maryland University.

As at many comparable colleges, over the last fifty years Notre Dame's relationship with its founding order has moved from one of hierarchical dominance to one of affiliation-or as the School Sisters of Notre Dame term it, "sponsorship," defined as "the mutually beneficial and dynamic relationship between the congregation and an organization in which the SSND charism and educational vision ... are defining characteristics of the organization's mission." ${ }^{114}$ To implement this interpretation, leaders of the college and the order established a sponsorship review process, adding in 2001 a vice president for mission to the college's governing structure. ${ }^{115}$ There is general agreement that this strategy has produced significant benefits. "It imparts to our sponsored colleges a culture that approaches education as more than individual enhancement," explained president emerita Mary Pat Seurkamp. "Sponsorship assumes a commitment to the Catholic intellectual tradition and to the values of the sponsoring religious congregation." 116

\section{Years of Catholic Women's Education}

As their original rationale - the refusal of elite men's colleges to admit women-evaporated during the 1960s and 1970s, women's colleges began to face the question of whether they ought to continue at all, a question that persists today. For fifty years young women in general have preferred coeducational to single-sex colleges, and Catholic philanthropy flows disproportionately to institutions, now coeducational, that were originally founded by and for men. As student interest in attending coeducational colleges climbed inexorably, women's colleges continued to argue that female students benefited relatively more from the single-sex than from the coeducational college experience. In 1987, President Kathleen Feeley offered a representative explanation: the College of Notre Dame, she said, "offers to girls and women a choice to which they have a right: the choice to be educated in an atmosphere in which they are the singular object of the educational enterprise... Today, women's colleges have a unique opportunity to nurture in women the special feminine qualities which have leavened our society even as they prepare women for a future of equality of influence through widely diverse channels." ${ }^{117}$ In making this argument, Feeley departed from the position of the 
founders of the College of Notre Dame. Offering women the opportunity to attend a Catholic college was indeed their priority, but the sisters themselves did not oppose the concept of coeducation. They founded a college for women because at the time Catholic undergraduate colleges admitted only men.

Catholic women's colleges, in other words, may have been something of a historical accident. Yet their social impact on female citizens remains distinctive. They paved new roads in private higher education, adding diversity to the types of colleges flourishing in the United States. As a result of the church's long-term opposition to coeducation, Catholic women's colleges spread from the Atlantic to the Pacific, and opened in rural as well as urban settings, broadening access to higher education, especially for the daughters of working- and middle-class families. From their inception, they advanced women's roles in the wider society as their graduates moved into positions of authority and power in church and state. Historically, they have represented major commitments of Catholic resources, both financial and human, to women. In their own way, these colleges reconfigured the Catholic Church in the United States.

Collectively, the numerous Catholic colleges also played a significant and underrecognized role in the women's college movement in the United States. If Catholic college women saw themselves as entering formerly closed, elite male realms, this was an experience they shared with the nineteenth-century founders of the Seven Sisters and with their peers at secular colleges throughout the twentieth century. Although both lay and religious women were always constrained by the need for episcopal approval, like their secular and Protestant counterparts Catholic women's colleges were significant female-dominated spaces within an otherwise overwhelmingly masculine power structure. Their campuses became places where women often formed significant social and professional bonds away from the eyes of bishops, fathers, and husbands, and where they could hold positions of real responsibility unavailable in other institutions. The achievements of the women who taught in them have had real and lasting effects on their communities.

For over a century, then, Catholic women's colleges have advanced women's intellectual and professional opportunities in American society. They played a key role in democratizing Catholic higher education by incorporating women into the enterprise, widening opportunities for working- and lower-middle-class women to attend private colleges. Their story is the story of how women became agents in their own right as citizens of society and of the nation's largest church. These institutions were able to defy a century 
of male primacy in the church's colleges only because of the financial and labor support of religious orders of women sustained over many decades. However, female dominance in their governance and faculties also had the negative effect of marginalizing these colleges in mainstream and church educational circles. As a result, the historical importance of Catholic women's colleges is only now coming into view.

This book has evaluated the historical experiences, successes, failures, and long-term significance in the history of Catholic women's colleges, as exemplified in the development of the first of their number, the College of Notre Dame of Maryland, over the course of the twentieth century. Tense debates around single-sex education, the value and place of the liberal arts curriculum, and Catholic institutional identity have marked discussion at the college over recent decades, as they have at similar schools in an era of simultaneous expansion and constriction. Have the college's original vision, values, and goals remained essentially unchanged, even as the forms in which they revealed themselves altered significantly over the passing decades? Is Notre Dame's present situation simply a variation on the college's original theme, or is it, in fact, a wholly new theme?

As the history recounted here shows, by the turn of the twenty-first century Notre Dame had broadened its boundaries dramatically. Its student body was now heterogeneous in race, religion, and gender. Its original women's undergraduate college was joined over time by a Weekend College that welcomed men as well as women students. It expanded its curriculum to include professional fields of study as well as the liberal arts and offered graduate as well as bachelor's degree programs. Far from the protective restrictions it had long placed on students, it actively developed cross-registration opportunities for its students with other institutions. ${ }^{118}$ By responding effectively to challenges from both mainstream society and the church community, Notre Dame transformed itself from an upper-middle-class, racially segregated institution to one of the most socially and racially diverse of the nation's private religiously affiliated colleges.

As in 1895, Notre Dame's focus on women and its commitment to the liberal arts remain fundamental to its character. Its determination to survive as an autonomous institution apart from Loyola explains, in large measure, its 1970 s decision to remain a women's college. Its success in maintaining and developing its own identity and position in the intervening decades means that if Notre Dame moves to further coeducation in the future, it will do so on its own terms. Meanwhile, its undergraduate women's college remains the core of the institution. The liberal arts are integral to professional programs of study, while liberal arts majors enjoy unique opportunities to elect 
courses in a range of professional fields. Its emphasis on science, which dated from its 1895 foundation, took on new dimensions in its School of Nursing and School of Pharmacy, and its historic commitment to the study of education grew as well; its first $\mathrm{PhD}$ was awarded in that field. Four decades of coeducation and the expansion of professional programs in Notre Dame's Weekend College and graduate programs in many ways enriched its undergraduate women's college. Since 1895, Notre Dame has preserved its commitment to women's higher education in the face of critical tests from church and society. The extent to which it achieved its original purposes is the judgment of history. 
